\title{
Exploration of Farmers' Preferences and Perceptions of Maize Varieties: Implications on Development and Adoption of Quality Protein Maize (QPM) Varieties in Zimbabwe
}

\author{
Lewis Machida $^{1,2}$, John Derera ${ }^{1}$, Pangirayi Tongoona ${ }^{1}$, Augustine Langyintuo ${ }^{2,3} \&$ John MacRobert $^{2}$ \\ 1 African Centre for Crop Improvement (ACCI), School of Agricultural, Earth and Environmental Sciences, \\ University of KwaZulu-Natal, Pietermaritzburg, Republic of South Africa \\ ${ }^{2}$ International Maize and Wheat Improvement Centre (CIMMYT), Harare, Zimbabwe \\ ${ }^{3}$ Alliance for a Green Revolution in Africa (AGRA), Nairobi, Kenya \\ Correspondence: Lewis Machida, International Maize and Wheat Improvement Centre (CIMMYT), P. O. Box \\ 1041-00621, Nairobi, Kenya. Tel: 254-20-722-4620. E-mail: 1.machida@cgiar.org
}

Received: July 5, 2013 Accepted: March 3, 2014 Online Published: March 25, 2014

doi:10.5539/jsd.v7n2p194

URL: http://dx.doi.org/10.5539/jsd.v7n2p194

\begin{abstract}
Quality protein maize (QPM) technology is relatively new in Zimbabwe and farmer awareness of QPM was low. Participation of smallholder farmers in the development of QPM breeding objectives and dissemination strategies was solicited through participatory rural appraisal (PRA) techniques. Seventy two farmers participated; the farmers were involved in the Mother Baby Trial (MBT) projects in four selected villages from three districts of Zimbabwe. Data collection techniques included work-sharing, village or resource mapping, Venn diagramming, semi structured interviewing, matrix scoring and ranking and pairwise ranking. The results suggested that protein malnutrition was prevalent in the districts. Maize was the most important crop and farmers grew three types of maize, namely landrace ("Hickory King"), open pollinated varieties (OPV) and hybrid varieties all representing normal endosperm maize. Hybrids were dominant and produced mainly for sale, while "Hickory King", although not supported by the formal seed system, continued to be produced for home consumption because of its superior taste, white kernel color, large kernel size, high kernel density, kernel hardness, and perceived weevil-resistance. Lateness and foliar disease susceptibility were the disadvantages of Hickory King. The ideal maize variety should be early-maturing, with a high yield potential, drought tolerant, foliar disease resistant and stem borer tolerant. For any QPM variety to be acceptable, farmers expected it to combine the agronomic attributes of hybrids and the grain quality characteristics of "Hickory King", an "heirloom" variety. To effectively promote the adoption of QPM, the Agricultural Research and Extension (AREX) arm of government was the farmers' choice compared to other modes of information dissemination which were radio, television, newspaper, church NGO and councillor.
\end{abstract}

Keywords: Quality Protein Maize (QPM), Participatory Rural Appraisal (PRA), heirloom variety, Hickory King, QPM adoption

\section{Introduction}

\subsection{Low Levels of QPM Adoption}

As in many countries in southern Africa, maize is a staple food crop in Zimbabwe (Rusike, 1998). Nearly all the varieties cultivated are normal endosperm maize and, hence, deficient in two essential amino acids, lysine and tryptophan. With the development of quality protein maize (QPM) varieties, there is hope for the provision of an affordable source of balanced protein to millions of inhabitants of the maize growing regions (Graham, Lembcke, \& Morales, 1990; Vasal, 2002). However, the adoption of QPM still remains low (Atlin et al., 2011) despite the recent demonstration of the effectiveness of QPM in improving the nutritional status of children at the village level by Gunaratna, Groote, Nestel, Pixley and McCabe (2010). The dissemination and adoption of QPM is still lagging behind normal endosperm maize especially in regions such as sub-Saharan Africa where it is needed most. In sub Saharan Africa, total maize area is estimated at 30 million hectares (FAOSTAT, 2012), and only less than 1\% (or 200000 hectares) was estimated to be under QPM (Krivanek, De Groote, Gunaratna, Diallo, \& Friesen, 2007) yet the requisite agronomic practices of both normal endosperm maize and QPM are alike (Vasal, 
2001) and there is no evidence of differences in agronomic performance between QPM and non-QPM genotypes under both moisture stressed and non-stressed test-environments (Atlin et al., 2011).

\subsection{Widespread Malnutrition}

Anthropometric measures of morbidity, wasting away, stunting and underweight in children aged zero to five years classified Zimbabwe as one of the countries with a high risk of malnutrition in sub-Saharan Africa yet QPM varieties adoption is still in the early stage. Protein-energy malnutrition is one of the factors contributing to the undesirable anthropometric measures and in Zimbabwe 19.9\% of the children were found to be underweight, $39.9 \%$ stunted, and $5 \%$ wasted and only $27.6 \%$ of the children were breastfed up to 24 months UNICEF, WHO, The World Bank (2012). On the other hand QPM is known to possess about $80 \%$ of the biological value of cow milk (Bressani, 1992). Therefore, there is a nutritional gap in the infant age group that can be filled up with a QPM complemented diet to improve nutritional security.

\subsection{Approaches to New Technology Adoption}

In Zimbabwe, currently there are no known commercial QPM cultivars available for the farmers but publicly available adapted germplasm was successfully evaluated and identified by Machida, Derera, Tongoona and MacRobert (2010). The first step in assisting farmers in accessing QPM grain is to develop the cultivars. Least cost cultivar development requires setting up of breeding goals, objectives and strategies according to those for normal endosperm maize since the two types of maize have similar agronomy (Vasal, 2001). This requires the use of secondary data to establish a general direction of the breeding objectives in Zimbabwe.

However, unlike other technologies, adoption of agricultural productivity-improvement technologies is overly constrained by social and cultural contexts when dealing with smallholder farming communities. The need for the involvement and participation of farmers in the development of new crop varieties for smallholder farmers was highlighted by DeVries and Toenniessen (2001). The importance of cowpea grain quality characteristics in targeting research was confirmed by Langyintuo et al. (2004) in a study of consumer preferences in West Africa. According to DeVries and Toenniessen (2001), farmers should be involved in all aspects of variety development that include priority setting, early generation breeding, variety testing and selection so that breeders obtain regular input from farmers that enables them to structure their selection indices accurately. Thus farmers should not be just technology recipients and beneficiaries but actors who influence and provide key inputs to the technology development process (Gonsalves et al., 2005). Based on empirical results, Langyintuo et al. (2004) recommended that cowpea breeding programs for the Ghanaian market should emphasise black eye colour but those for the Cameroonian markets should avoid black-eyed grains. In Malawi, because of poor interactions with the farmers, breeders of the national maize program produced improved high yielding dent varieties of poor grain characteristics such as milling qualities and consequently not adopted by farmers who preferred flint grains for home consumption (Smale \& Heisey, 1994). Also Derera, Tongoona, Langyintuo, Laing and Vivek (2006) reported the continual use of landraces by the farmers in the eastern belt of Zimbabwe despite the availability of new and high yielding hybrid varieties.

The use of secondary data alone in setting QPM breeding objectives and dissemination strategies has been criticized by DeVries and Toenniessen (2001) but could still be adopted under budgetary limitations. According to Rubey, Ward and Tschirley (1997), three approaches can be pursued to incorporate farmers' preferences in the early stages of research planning. These are the "political approach", the "presumptive approach", and the survey approach. They asserted that both the political approach where the interests of the most powerful users is catered for, and the presumptive approach where researchers implicitly and explicitly make assumptions about what the users need were found to be associated with high costs in designing maize breeding programs. The potentially high costs stem from the fact that the produced variety could easily be unacceptable to the users (Smale \& Heisey, 1994) and also some essential genetic material could be erroneously excluded from the active genetic pool because of incorrect notions about what the users want. Due to these limitations, Rubey et al. (1997) suggested an alternative approach for incorporating maize users' preferences into breeding strategies by using survey data on consumer preferences.

Earlier on Chambers (1994a) advocated for the use of the Participatory Rural Appraisal (PRA) technique, arguing that the technique empowers the people to generate, analyze, share and own the generated information contrary to the views of Gladwin, Peterson and Mwale (2002) that PRA techniques were necessary but not sufficient because they overlook the heterogeneous nature of farmer behaviour and there is no procedure to validate the universality of conclusions reached or constraints identified. An example of where QPM was introduced successfully in Africa is in Ghana where the promotional activities involved the national policy makers (State President), health ministry, research and extension departments, Sasakawa Global 2000, and radio 
and television broadcasts (Twumasi-Afriye, Dzah, \& Ahenkora, 1996). In addition the researchers in Ghana disapproved several myths about QPM and linked up very well with both the seed producers and industrial users of QPM grain. It is not indicated whether they conducted PRAs but their approach involved creating a good rapport with all the stakeholders involved in the production and utilization of "Obatanpa" (QPM). "Obatanpa" literally means the good nursing mother.

\subsection{Farmer Solicitation in Setting up QPM Breeding Goals and Dissemination Strategies}

Although Gladwin et al. (2002) recommended combining participatory approaches with scientific rigor and testing, several reports indicate that participation was sufficient to guarantee favorable outcomes of projects (Narayan, 1993; Pretty \& Voudouhue, 1996; Cleaver, 2001; Godfrey \& Obika, 2004; Prokopy, 2005). Can the participatory rural appraisal technique be used successfully to set QPM breeding goals and objectives in Zimbabwe? The postulation was that farmers have preferences and perceptions on maize varieties and these have implications for QPM varieties breeding and dissemination. The objective of the study was to solicit the participation of smallholder farmers in the development and setting up of QPM breeding goals, objectives and dissemination strategies. The approach served to preempt any potential problems that might arise in the adoption of QPM cultivars by smallholder farmers in Zimbabwe. Bellon (2001) pointed out that to contribute effectively to farmers' welfare by providing new information and technologies then researchers need to first understand farmers' knowledge about their crops, farming environment and socioeconomics.

\section{Method}

\subsection{Sampling Procedure and Study Sites}

The convenience sampling approach (Saunders, Lewis, \& Thornhill, 1997) was used to select three districts (Murehwa, Wedza, \& Zvimba) out of the 52 districts in Zimbabwe based on their proximity to Harare, the base station for International Maize and Wheat Improvement Center (CIMMYT) Zimbabwe. The three districts are located in agro ecological zones (Natural Region II) where the rainfall is above $700 \mathrm{~mm}$ per annum and, hence, are suitable for maize production. In these districts, some "embryonic" work on QPM had also been conducted in the previous cropping seasons through the Mother and Baby Trial (Note 1) (MBT) (Snapp, 2002) activities organized by the department of Agricultural Research and Extension (AREX).

In each district, a purposive sampling approach (Saunders et al., 1997) was used in identifying the groups of farmers for the PRA exercises. Groups of farmers that participated in the 2006/7 MBT were targeted as the nucleus but those that had not participated in the MBT were also included. The earlier group of farmers was expected to have some knowledge about QPM because a QPM variety was included in the MBT experiments. For the convenience of the farmers and ease of contrasting the phenotype of a typical QPM hybrid variety to normal maize plants, extra plots of ZS261, a QPM hybrid variety were planted in all Baby Trial sets that initially did not have a QPM variety.

The PRA exercises were conducted during May to June 2007 when most smallholder farmers were expected to be less busy. The districts, the villages, and the numbers of participants are listed in Table 1.

Table 1. Selected districts, villages and number of farmer participants for PRA activities

\begin{tabular}{llccc}
\hline \multirow{2}{*}{ District } & \multirow{2}{*}{ Village } & \multicolumn{3}{c}{ Number of Farmers } \\
& & Female & Male & Total \\
\hline Zvimba & Njiri & 8 & 8 & 16 \\
Wedza & Payarira & 18 & 7 & 25 \\
Murehwa & Chiweshe & 6 & 4 & 10 \\
Murehwa & Chidawaya & 15 & 6 & 21 \\
Total & & 47 & 25 & 72 \\
\hline
\end{tabular}

\subsection{QPM Subject Introduction}

The opening of PRA meetings in all the four villages followed a standard procedure starting with formal discussions with AREX staff on the objectives of the PRA and introduction of the PRA team to the farmers by the AREX staff followed by the subject of QPM by the facilitator. Highlights of the introduction were awareness of the existence of QPM, the nutritional advantages of QPM, and the need for isolation from normal maize crops 
in order to maintain the nutritional superiority of QPM over normal maize. Farmers were then asked to highlight any unusual aspect that they observed about ZS261, the QPM variety that was grown in the 2006/7 MBT trials.

\subsection{Participatory Rural Appraisal Techniques}

The following techniques by Chambers (1994a), Cornwall, Gujit and Wellbourn (1993) and Pretty, Guijt, Scoones and Thompson (1995) and cited by Campbell (2002) were used to collect the data:

a) Work-sharing: harvesting of MBT trials together with the farmers so as to create a rapport between the researchers and the farmers prior to the PRA

b) Village or social or resource mapping was used by farmers to introduce their environments and surroundings to the PRA facilitators and in the process created a good rapport between the two groups. The farmers had the opportunity to draw maps of their villages and surroundings indicating the important features in the maps. Establishment of a good rapport was paramount for the conduct of the later activities.

c) Venn diagrams were employed in the identification of important institutions in the maize production and consumption systems. Smaller circles indicated less important whilst bigger circles indicated more important.

d) The identification and ranking of problems and constraints related to maize production and utilization was done using matrix ranking and scoring. Three categories of different seed types namely Landrace (Hickory King), Open Pollinated variety (OPV), and Hybrid were recognized in all the villages. Farmers (split according to gender where applicable) used different objects to represent the different categories of seed type whilst scoring (indication of preference or importance) was done using maize cobs cores. A high number of maize cobs cores indicated preference (or high importance) whilst a low number indicated less preference (or less importance) for the category. Farmers' perceptions about the relative importance of the problems and constraints were established for each village. Where applicable, pair wise ranking techniques were employed. The role and significance of different varieties grown by the farmers and their attributes were investigated using either matrix ranking and scoring, or pair wise ranking techniques.

e) Semi-structured interviews were conducted to investigate the nature and extent of problems and for probing to get more information on various subjects of discussion.

f) For PRA activities or exercise where the farmers' groups were too large the groups were split according to gender for easier management of discussions within a village.

g) Farmers' preferred modes / means of disseminating QPM technology information were investigated through the pairwise ranking technique. Alternative modes of dissemination like radio, television, newspaper, farmer magazine, AREX, councilor, church, and non-governmental organization were considered in pairs and farmers had to indicate their preferences as a group.

\section{Results}

\subsection{QPM Awareness and Malnutrition Levels}

The discussions during the opening of the PRA meetings indicated that there was low awareness of QPM in all the four villages. Interviews with Nutrition / Health workers in the Njiri and Payarira villages confirmed the prevalence of protein malnourishment which could potentially lead to kwashiorkor (Note 2) (MedicineNet.Com 1998). The farmers in all the four villages were enthusiastic about the possibility of growing QPM and all were committed to provide the necessary isolation requirements to prevent outcrossing with normal maize.

\subsection{Relative Importance of Crops Grown by Farm Households}

In the four villages, a total of 13 different crops are grown by farmers (Table 2). Scoring done by the farmers suggested maize (Zea mays L) as the most important crop in all villages followed by groundnuts (Arachis hypogea L.) except in Chiweshe where groundnut was third to finger millet (Eleusine coracana L.), a crop that was the third most important in Njiri, ranked very low in Payarira, and not mentioned in Chidawaya. Sweet potato (Ipomoea batatas L.) ranked third in Njiri but fourth in the other three villages. Bambara groundnut (Vigna subterranea), a crop that is both rich and balanced in protein was ranked lowly in all the villages except in Payarira village where it was ranked as the third most important. Crops not listed in some villages were cucumbers (Curcubit spp), tobacco (Nicotiana tabacum), sunflower (Helianthus annus), soyabeans (Glycine max L.) and okra (Hibiscus esculentus L.). 
Table 2. Relative rankings of crops grown in each of the four villages

\begin{tabular}{lcccc}
\hline Crop & Payarira & Njiri & Chidawaya & Chiweshe \\
\hline Bambara groundnut & 3 & 10 & 5 & 9 \\
Bean & 8 & 6 & 7 & 8 \\
Cowpea & 4 & 5 & 6 & 7 \\
Cucumber & 9 & $*$ & $*$ & $*$ \\
Groundnut & 2 & 2 & 2 & 3 \\
Maize & 1 & 1 & 1 & 1 \\
Okra & 9 & 7 & $*$ & $*$ \\
Finger millet & 9 & 3 & $*$ & 2 \\
Sorghum & 9 & 9 & 8 & 6 \\
Soya bean & 7 & 11 & 4 & $*$ \\
Sunflower & 9 & 8 & $*$ & 5 \\
Sweet potato & 4 & 4 & 3 & 4 \\
Tobacco & 9 & $*$ & $*$ & $*$ \\
\hline
\end{tabular}

* Crop not listed in village; 1 = most important; 9 = least important.

\subsection{Maize Varieties Grown in Each of the Villages}

Table 3. Varieties of maize grown in each of the four villages

\begin{tabular}{|c|c|c|c|c|c|}
\hline Variety & Name & Payarira & Njiri & Chidawaya & Chiweshe \\
\hline Hybrid & AC 31 & $\sqrt{ }$ & & $\sqrt{ }$ & $\sqrt{ }$ \\
\hline Hybrid & AC71 & $\sqrt{ }$ & & $\sqrt{ }$ & \\
\hline OPV, Landrace & Hickory King & $\sqrt{ }$ & $\sqrt{ }$ & $\sqrt{ }$ & $\sqrt{ }$ \\
\hline Hybrid & PAN 413 & & $\sqrt{ }$ & & $\sqrt{ }$ \\
\hline Hybrid & PAN 6479 & $\sqrt{ }$ & & & \\
\hline Hybrid & PAN 67 & & $\sqrt{ }$ & & \\
\hline Hybrid & PHB 30G19 & $\sqrt{ }$ & & & \\
\hline Hybrid & PHB 30G97 & & & & $\sqrt{ }$ \\
\hline Hybrid & PHB 3253 & $\sqrt{ }$ & & & \\
\hline Hybrid & R 201 & $\sqrt{ }$ & & & \\
\hline Hybrid & SC 403 & $\sqrt{ }$ & & & $\sqrt{ }$ \\
\hline Hybrid & SC 411 & $\sqrt{ }$ & $\sqrt{ }$ & & \\
\hline Hybrid & SC 513 & $\sqrt{ }$ & $\sqrt{ }$ & $\sqrt{ }$ & $\sqrt{ }$ \\
\hline Hybrid & SC 517 & $\sqrt{ }$ & & & $\sqrt{ }$ \\
\hline Hybrid & SC 628 & $\sqrt{ }$ & $\sqrt{ }$ & & \\
\hline Hybrid & SC 633 & $\sqrt{ }$ & & $\sqrt{ }$ & \\
\hline Hybrid & SC631 & & & $\sqrt{ }$ & \\
\hline Hybrid & SC635 & & $\sqrt{ }$ & $\sqrt{ }$ & \\
\hline Hybrid & SC636 & & $\sqrt{ }$ & & \\
\hline Improved OPV & ZM 521 & $\sqrt{ }$ & $\sqrt{ }$ & $\sqrt{ }$ & $\sqrt{ }$ \\
\hline Improved OPV & ZM421 & & $\sqrt{ }$ & $\sqrt{ }$ & \\
\hline
\end{tabular}

Key: $\sqrt{ }=$ variety grown by villagers; OPV $=$ Open Pollinated Variety. 
The most popular varieties of maize, the dominant food crop, among the about 14 planted in the four villages were hybrid SC513, improved OPV ZM521 and the landrace "Hickory King" (Table 3).

A closer look at the different types of seed planted suggested that farmers preferred hybrids to OPV and landraces except for the males in Chidawaya (Table 4) where their preference for OPV versus landraces differed by gender. Reasons for farmers' preference for hybrids included their high yield potential, good tolerance to drought, good levels of resistance to diseases and insect pests, availability and easy access to seed in adequate quantities, and well adaptability to their environments. Those that preferred the OPVs perceived that they were more drought tolerant than the hybrids. They also perceived that OPVs were early maturing and therefore had the potential of providing early harvests to poor farmers. In addition, OPVs could be recycled without much loss of plant vigor thereby saving on seed cost in the subsequent three to four years after purchase.

Table 4. Translated maize cob cores scores on varietal preferences in each of the villages

\begin{tabular}{cccc}
\hline Village & Variety & \multicolumn{2}{c}{ Scoring } \\
& & Males & Females \\
\hline Njiri & Hybrid & 10 & 12 \\
& OPV & 4 & 5 \\
Payarira & "Hickory King" & 6 & 3 \\
& Hybrid & 15 & 33 \\
Chiweshe & OPV & 1 & 19 \\
& "Hickory King" & 4 & 6 \\
& Hybrid & 9 & 7 \\
& OPV & 5 & 3 \\
Chidawaya & "Hickory King" & 1 & 2 \\
& Hybrid & 14 & 10 \\
& OPV & 33 & 8 \\
& "Hickory King" & 21 & 5
\end{tabular}

N.B. The total number of maize cobs cores used for each village was decided by the farmers.

\subsection{Farmers' Perception of Hickory King - Heirloom Variety}

Seed companies discontinued to produce and sell seed of Hickory King more than 30 years ago and hence farmers revealed that they adopted both temporal and spatial isolation strategies to maintain its seed stock. "Hickory King" was perceived to have desirable taste, higher flour retention when dehulled before milling, extremely white flour for making white "sadza", denser and bigger kernels, better resistance to maize weevils than improved seeds, stable yield levels year after year, and recyclable seed. "Hickory King" could easily be contaminated by yellow maize but fortunately the flowering period of "Hickory King" and most other varieties did not overlap because of the practiced different times of planting, and maturity. At harvest farmers selected well filled eight rowed ears for use as seed in the following cropping season. In storage, some of the farmers treated their "Hickory King" seed with "Shumba-Cooper" a grain storage pesticide containing fenitrothion (O,O-Dimethyl O-(3-methyl-4-nitrophenyl) phosphorothioate) and deltamethrin ((S)--cyano-3-pehoxybenzyl(1R)-cis-3-(2,2-dibromovinyl)-2,2-dimethylcyclopropane carboxylate) as active ingredients or with fine chaff from finger millet (Eleusine coracana L). Others simply hung the "Hickory King" cobs above fireplaces until the next planting season. The practice was investigated and found to be beneficial to indigenous maize seeds by Modi (2002 \& 2004).

Because of its perceived grain qualities, farmers grew "Hickory King" mainly for home consumption and other varieties for the market if they had to sell. Further investigation on farmers' claim of resistance to weevils revealed that weevil-damaged seed lots of "Hickory King" germinated better than weevil-damaged hybrid seed lots because the larger size of the "Hickory King" kernels made it possible for the germ to escape the weevil damage. For this reason, "Hickory King" was treasured like gold in Payarira village: Those who had the seed did not want to share it with others because they claimed that it was their secret weapon to guarantee their being 
considered the best farmers in their area. In Chidawaya village the farmers liked the "Hickory King" variety to the extent that it was affectionately known as "Mabhagu" meaning "the big ones" in reference to the kernel size. In Chidawaya village, the farmers estimated that when "Hickory King" flour was produced through the refined milling process the farmers were able to retain $75 \%$ of the original volume of grain whereas with the hybrid varieties and open pollinated varieties only about $50 \%$ of the original volume of grain was retained as flour.

\subsection{Farmers Preferences for Maize Traits}

The list and the rankings of traits considered important in maize production, which could be used to select QPM varieties by breeders are presented in Table 5. There were few agreements across villages in the ranking of attributes but generally agronomic attributes were more important than quality attributes. The most important traits were yield potential (Payarira and Chiweshe villages), early maturity (Njiri village) and stem borer resistance (Chidawaya village). Although farmers argued that they grew "Hickory King" because of its quality attributes (taste, flour color, kernel size) only two villages (Chidawaya and Chiweshe) listed taste and kernel size as important attributes. However these quality attributes were rated lowly compared to agronomic attributes like yield potential, drought tolerance, disease resistance, and maturity group probably implying that farmers were less sensitive to quality attributes than agronomic attributes.

Table 5. Pairwise ranking of important maize attributes by farmers in Njiri, Payarira, Chidawaya and Chiweshe

\begin{tabular}{lcccc}
\hline Maize trait & Njiri & Payarira & $\begin{array}{c}\text { Village } \\
\text { Chidawaya }\end{array}$ & Chiweshe \\
\hline Yield potential & 3 & 1 & 4 & 1 \\
Early maturity & 1 & - & - & 2 \\
Drought tolerance & 2 & 5 & 2 & 3 \\
Taste & - & - & 7 & - \\
Disease resistance & 5 & 3 & 2 & 4 \\
Earliness to maturity & - & - & 4 & - \\
Stem borer resistance & - & - & 1 & - \\
Weevil resistance & - & 6 & 6 & 8 \\
Adaptation & - & 4 & - & - \\
Medium maturity & - & 2 & - & - \\
Seed Price & 4 & - & - & - \\
Pest resistance & 6 & - & - & - \\
Tolerance to low soil fertility & - & - & - & 7 \\
Good husk cover & - & - & - & 8 \\
Big kernel size & - & - & - & 5 \\
Termites resistance & - & - & - & 11 \\
${ }^{+}$Apomictic characteristic & - & - & - & 6 \\
Lodging resistance & - & - & - & 10 \\
\hline
\end{tabular}

${ }^{+}$Ability to set seed without sexual mating so that farmers avoid buying seed every season.

\subsection{Farmers' Perception of Attributes of the Three Different Types of Seed (Varieties)}

The perceptions of farmers in Payarira, Chiweshe and Chidawaya villages about the attributes in the three types of seed are presented in Table 6. The list of traits used in the analysis in each village was constructed by farmers. Five, six and seven traits were used in the ranking in Chiweshe, Payarira and Chidawaya villages respectively. There was no clear trend in perception of attributes in the different types of varieties across the villages. Across the villages, only yield potential, disease tolerance and drought tolerance were common. Weevil resistance was common in Payarira and Chidawaya whilst earliness was common in Chiweshe and Chidawaya. Maize variety adaptation and medium maturity were identified as important traits in Payarira village, whilst kernel size was 
listed as an important trait in Chiweshe. Grain taste and stem borer resistance were listed as important traits in Chidawaya village. Although kernel size and grain taste traits were identified as important in variety choice by only one village for each of the two traits, the importance of the two traits also emerged from structured discussions across all the four villages. Overwhelmingly, the old OPV "Hickory King" was perceived to have the most desirable grain taste, large kernel size and hard kernels which are the "ideal traits" required by farmers.

Table 6. Farmers' perception of attributes in different categories of maize varieties

\begin{tabular}{llccc}
\hline Village & \multicolumn{1}{c}{ Trait } & Hybrid & OPV & "Hickory King" \\
\hline Payarira & Yield potential & 4 & 2 & 5 \\
& Adaptation & 4 & 1 & 5 \\
& Medium maturity & 5 & 2 & 5 \\
& Disease tolerance & 4 & 4 & 5 \\
& Drought tolerance & 3 & 5 & 4 \\
& Weevil resistance & 2 & 4 & 5 \\
Chiweshe & Yield potential & 4 & 3 & 5 \\
& Earliness & 5 & 3 & 1 \\
& Drought tolerance & 5 & 2 & 3 \\
& Disease tolerance & 3 & 2 & 4 \\
& Kernel size & 4 & 3 & 5 \\
Chidawaya & Yield potential & 5 & 5 & 3 \\
& Weevil resistance & 3 & 5 & 5 \\
& Drought tolerance & 4 & 5 & 2 \\
& Taste & 3 & 5 & 5 \\
& Disease tolerance & 4 & 5 & 5 \\
& Earliness & 5 & 5 & 3 \\
& Stem borer resistance & 3 & 5 & 5
\end{tabular}

Key: $1=$ poor and $5=$ very good. N.B. There was no opportunity to conduct the ranking exercise in Njiri Village (Zvimba).

In Payarira, Hickory King scored 5 for all the traits except for drought tolerance where it had a score of 4 . They perceived hybrid varieties to be equal to OPVs for disease tolerance but better than open pollinated varieties in all the other traits except drought tolerance and weevil resistance.

In Chiweshe village, open pollinated varieties were perceived to be inferior to both hybrids and "Hickory King" for all the traits except for earliness which was better than that for "Hickory King". "Hickory King" was rated the best for both yield potential and kernel size. Farmers considered hybrid varieties as the best in terms of earliness to maturity and drought tolerance.

In Chidawaya village open pollinated varieties were scored 5 for all the attributes except for stem borer resistance, which was rated 4 . Hybrid varieties were rated 5 for both yield potential and earliness but were rated the worst for weevil resistance, stem borer resistance and taste. Farmers considered "Hickory King" the best variety for stem borer resistance, taste, disease tolerance and weevil resistance but it had the lowest scores for yield potential, drought tolerance and earliness to maturity. Farmers in all the four villages indicated the attributes desired in a QPM variety as extremely white, large, flat, hard, weevil resistant, relatively denser kernels with taste similar to that of "Hickory King" and with a relatively high yield potential.

\subsection{Important Organisations in the Production of QPM Varieties}

Table 7 ranks the Njiri and Payarira farmers' lists of organizations that are important in the production of maize and hence the promotion, adoption and production of QPM varieties. Both Njiri and Payarira villages recognized AREX as the most (first) important organization in the production of maize and the Agricultural and Rural 
Development Authority as the eighth most important but differed in the rankings (and listing) of the remaining organizations.

Table 7. Ranking of the relative importance of organizations by farmers

\begin{tabular}{lcc}
\hline Organization & \multicolumn{2}{c}{ Village } \\
& Njiri & Payarira \\
\hline AREX & 1 & 1 \\
Agribank & 2 & - \\
Zimbabwe Farmers Union & 3 & - \\
Grain Marketing Board & 4 & 2 \\
Seed Co & 6 & 3 \\
Pioneer Seeds & 7 & 5 \\
Pannar Seeds & 10 & 6 \\
Zimbabwe Fertilizer Company & 5 & 4 \\
Agricultural and Rural Development Authority & 8 & 8 \\
Cargill & 9 & \\
Agpy Seeds & - & 7 \\
\hline
\end{tabular}

According to Njiri village farmers' opinion, AREX was the most important organization to them in the production of maize followed by Agribank (Note 3), and then Zimbabwe Farmers Union (ZFU). The Grain Marketing Board, which provided them with inputs through the government input supply programs, was ranked fourth followed by the Zimbabwe Fertilizer Company (ZFC) and Seed Co, Pioneer, Agricultural and Rural Development Authority (ARDA), Cargill and Pannar, in that order. The fact that Agribank was ranked second showed the role that credit plays in these farmers' maize production systems. The farmers valued access to and availability of credit more than anything else except support from AREX. The farmers perceived Seed Co Ltd to be the most important seed company in their community and could be used as conduit for the promotion of QPM. In Njiri village, ZFU membership made farmers eligible for benefits that came through other organizations and hence it was considered the next important organization after Agribank.

In Payarira AREX was ranked as the most important organization followed by GMB. According to the farmers, AREX interacted with GMB. After GMB the farmers reported Seed Co Ltd as the most important seed company followed by the Zimbabwe Fertilizer Company, Pioneer, Pannar, Agpy and ARDA. Thus the fertilizer companies were perceived to be playing a role bigger than that of Pioneer but smaller than that of Seed Co Ltd.

\subsection{QPM Information Dissemination}

The farmers in the four villages listed and ranked the ways and means of accessing new information in their area, and thus indicated information dissemination techniques or methods that could be useful in QPM promotion and adoption (Tables 8). There was consensus across the four villages in AREX as the first choice for mode of QPM information dissemination. Three of the four villages (Njiri, Payarira and Chiweshe) concurred in ranking the radio as the second most important mode of information dissemination. Television set, Farmers Magazine and Newspaper were ranked third (Payarira and Chiweshe), fourth (Payarira and Chiweshe) and fifth (Njiri and Payarira) most important modes of information dissemination respectively. The church, Commutech and councilor were each listed and ranked in one village only. 
Table 8. Preferred modes of QPM information dissemination from pairwise ranking

\begin{tabular}{lcccc}
\hline Source & \multicolumn{4}{c}{ Ranking by Village } \\
& Njiri & Payarira & Chiweshe & Chidawaya \\
\hline AREX & 1 & 1 & 1 & 1 \\
Radio & 2 & 2 & 2 & 4 \\
Television set & 4 & 3 & 3 & 6 \\
Newspaper & 5 & 5 & - & \\
Farmers magazine & 6 & 4 & 4 & 5 \\
Church (Cadec) & 3 & & & \\
Commutech & & & & 2 \\
Councillor & & & & 3 \\
\hline
\end{tabular}

Understanding of information on QPM appeared variable among the farmers. According to the Njiri farmers' understanding about the subject of QPM and its potential benefits their local term for QPM was "Godzamhuri" which means family-nourisher. In Payarira the farmers unanimously agreed on the term "Mupedzakwashi" which means "kwashiorkor terminator". In both Chiweshe and Chidawaya villages of Murehwa, the farmers could not come up with a local term for QPM.

\section{Discussion}

In Njiri and Payarira village the authorities responsible for community health and nutrition noted the existence of the problem of malnutrition affecting the poor and the orphaned families in both villages, which was confirmed by the farmers. The immediate short term solution would be to implement feeding programs. However, feeding programs are often unsustainable because they can be adversely affected by factors influencing accessibility of the area such as poor infrastructure (Andersen, 2003) and political instability. Delivery of the nutrition enhancing technology through improving the nutritional value of the staple crop such as QPM is the best sustainable option available since maize is the most important staple food crop in the country.

Farmers grow hybrids, improved open pollinated varieties and a local variety (landrace). "Hickory King", a local variety, was important to the maize farming systems contradicting official reports by Doswell, Paliwal and Cantrell (1996) that maize area in Zimbabwe is $100 \%$ hybrid. Hybrid varieties, which replaced most of the OPVs production area about thirty years ago, definitely play an important role in the maize cropping systems in the three districts mainly because of their availability, better adaptation, high yield potential and tolerance to diseases and insect pests. Nevertheless, there were still persistent pockets of "Hickory King" because of farmer preferences for its high kernel density, intense white flour color, desirable taste of food preparations, high level of flour recovery during pounding or refined milling, perceived tolerance to drought and foliar diseases, perceived resistance to weevils, and perceived higher yield levels. Some farmers could not plant their whole annual maize crop to "Hickory King" because of lack of adequate seed. Farmers in all the villages confessed that growing of improved open pollinated varieties is a practice that they adopted because of shortage of hybrid maize seed during the period of 2002/3 to 2006/7.

Maize is a controlled grain in Zimbabwe and only the parastatal, Grain Marketing Board (GMB), is authorized to buy it. This has implications for QPM that is not consumed on the farm. If urban and other consumers are to benefit from the QPM technology, separate marketing and storage arrangements have to be made for QPM varieties. A single handling system for both QPM and normal maize would diminish the potential benefits of QPM. The other question to be addressed is should there be a premium on QPM seed and grain? The presence of a premium is likely to discourage consumers from consuming QPM. On the other hand, lack of a premium on QPM seed might discourage private seed companies from devoting a lot of resources to QPM breeding. The contentious questions, therefore, are: If there is a premium to be paid on QPM, who pays it since the consumers are not willing to do so? But if there is no premium, who produces the seed since most seed companies are not willing to do so? In this case deploying new QPM varieties as synthetics could be better since farmers can try to maintain their seed for several seasons before getting fresh seed. Since they are currently able to maintain Hickory King, as long as they like the newly introduced QPM variety this should be feasible 
Across all the villages, hybrid varieties were preferred by the farmers despite their perceived weaknesses except the male farmers in Chidawaya village who preferred OPV because the OPV seeds could be easily recycled. In developing QPM cultivars, therefore local breeders should consider OPVs as well. These have the advantage of competing well with "Hickory King". However in areas where there is a lot of normal maize growing in the vicinity of open pollinated QPM varieties, the farmers would need to be discouraged from recycling seed if it is possible but if there is no option then they can be advised to harvest ears for seed from the center of their plots (Machida, Derera, Tongoona, Mutanga, \& MacRobert, 2012).

The top six attributes farmers perceived as desirable for maize cultivars and by extrapolation for QPM cultivars are yield potential, earliness, drought tolerance, resistance to weevils, resistance to stem borers, and resistance to foliar diseases. Although ranked differently from village to village, grain yield and earliness were among the top three. Farmers in Payarira and Chiweshe villages ranked them similarly but slightly different from those in Chidawaya village. For disease and drought tolerance, farmers' perceptions differed from village to village as indicated by the ratings. The demand for both high yielding and early maturity in the same cultivar has implications for both normal and QPM breeding in general because the two traits are negatively associated and, hence, it is difficult to maintain them in the same genotype. However, it is important to acknowledge that for the farmers to voluntarily grow and consume the QPM grain, these six attributes need to be combined with the desirable attributes of "Hickory King" which are large kernel size, high kernel density, intense white color, kernel hardiness, and the desirable taste. According to Twumasi-Afriye et al. (1996) this approach worked in Ghana when the QPM trait was bred into soft, white and dent backgrounds which were already popular and preferred by both farmers and housewives. Before then all the QPM varieties released in Ghana were not accepted by the farmers because they lacked the preferred background phenotype.

Each of the four villages acknowledged the growing and production of "Hickory King" and it should be borne in mind that although the color, taste, kernel shape and size, number of rows could still be typical of the original "Hickory King" variety, the other agronomic attributes such as yield, disease and insect tolerance, maturity category could have been affected through genetic drift emanating from the "Founder Effect" if measures were not taken to keep broad the genetic base of "Hickory King" parents for the succeeding generation (Falconer \& Mackay, 1996). Thus, some of the agronomic attributes of "Hickory King" are likely to be different from village to village depending on parents selected by the farmers and foreign pollen contamination levels in each generation. Therefore if "Hickory King" is to be used as base germplasm then "Hickory King" germplasm collection missions should be conducted so as to include all the potentially useful "Hickory King" traits in a QPM breeding program.

Farmers across all the four villages considered AREX represented by the local AREX officer as the most preferred mode for QPM information dissemination followed by the radio in three villages. In general the farmers had less preference for the radio, television set, newspapers, and the farmers' magazine. The potential role of nongovernmental organizations in promoting new technology was established in two of the villages. The potential influence of national politics in the power relations in the community was observed on the insistence that the village councilor could be used as a medium of communication in Chidawaya village. Several organizations including AREX, GMB, fertilizer companies, and seed companies were listed as important in the growing and promoting of maize. Among the seed companies, Seed Co Ltd was prominent because of the performance, availability and awareness of its products by the farmers. Therefore, marketing a new QPM product through the Seed Co Ltd brand would likely lead to a better chance of adoption.

Farmers mainly grew "Hickory King" for home consumption and not for sale, and only ate "sadza" from other varieties when the supply of "Hickory King" grain was depleted. Grain from hybrid varieties was freely sold. This suggested that a QPM variety that does not meet the desired characteristic of "Hickory King" could still be produced by the farmers and not consumed but sold to GMB since farmers prefer to consume "Hickory King". This can potentially defeat the objective of trying to improve nutrition at the smallholder farmer level. A similar experience was observed in Malawi where farmers would grow both hybrids and landrace OPVs and keep the landrace OPVs for home consumption because of their desirable flint characteristic but sell the dent hybrid varieties grain to the state authorities (Smale \& Heisey, 1994). The introduced QPM varieties should have "Hickory King" attributes to enhance adoption by the smallholder farmers. This requires the creation of base populations combining the available QPM germplasm and "Hickory King" germplasm. When extended to other countries, beneficial traits of the QPM germplasm can be combined with farmer-preferred traits of local "heirloom" varieties to enhance adoption.

Two local names that farmers suggested for QPM were "Godzamhuri" and "Mupedzakwashi". "Godzamhuri" is interpreted to mean "family-nourisher" whilst "Mupedzakwashi" means "kwashiorkor-terminator". Both names 
are potentially suitable in taking the QPM message to other smallholder farmers in Zimbabwe who have not heard about QPM before. There could be need to probe certain issues further through a survey, such as in villages where the rankings for certain topics of discussion were not the same across gender, and even on subjects of discussion where the farmers had a consensus it would be intellectually fulfilling to use the results as content for triangulation through a questionnaire based survey.

\section{Conclusion}

The awareness of QPM by the farmers was low and so PRA activities were related to normal endosperm maize but effectively contributed towards the setting up of goals for QPM breeding. Farmers listed the most preferred traits in maize varieties as high yield potential, earliness, drought tolerance, disease resistance, and pest resistance but there were slight differences in rankings for each village. The "Hickory King" "heirloom" variety was preferred for its superior grain taste, large kernels, hard kernel, white flour, and weevil resistance. The inclusion of these attributes in a new QPM variety could potentially lead to quick adoption. Agricultural Research and Extension (AREX) was identified as the most important organization working with maize across all the four villages, indicating that new QPM varieties can be disseminated via this agent. The most preferred means of disseminating QPM information was through the local AREX representative. Whilst the presumptive approach to QPM breeding goal setting was going to capture most of the important agronomic traits, it would have missed out on the quality aspects that make farmers prefer "Hickory King" to the normal varieties. Use of the PRA technique in both QPM breeding goal setting and appraisal of dissemination strategies was an improvement over use of the presumptive technique. The presumptive technique could result in farmers growing the QPM varieties for sale and not for consumption, which would defeat the goal of wanting to improve the nutrition of the vulnerable population in remote rural areas. Therefore, when breeding new QPM varieties for the rural communities it is important to combine the grain taste, large kernel, hard kernels, kernel density, and intense white color of "Hickory King" with drought tolerance, high yield potential, diseases resistance and earliness so as to enhance adoption. It can also be recommended to convert Hickory King to QPM without altering its key traits. These findings underscore the importance of smallholder farmers' participation not only in QPM breeding goal-setting but also on why it is important to incorporate smallholder farmer preferences in the breeding of crop varieties in general.

\section{References}

Andersen, P. (2003). Micronutrient strategies for marginal areas. Revised version of a paper presented at the IGU international conference on geographical marginality: Opportunities and constraints, February 3 -9, 2003 Geographi Bergen Arbelder fra Institutt for geografi - Bergen No 256 - 2003, Kathmandu/Pokhara.

Atlin, G. N., Palacios, N., Babu, R., Das, B., Twumasi-Afriye, S., Friesen, D. K., ... Pixley, K. V. (2011). Quality Protein Maize: Progress and Prospects. In J. Janick, Plant Breeding Reviews, 34, 83-130. http://dx.doi.org/10.1002/9780470880579.ch3

Bellon, M. R. (2001). Participatory research methods for technology evaluation: A manual for scientists working with farmers. Mexico, D. F.: CIMMYT. Retrieved from http://repository.cimmyt.org/xmlui/bitstream/handle/10883/1023/74275.pdf?sequence=1

Bressani, R. (1992). Nutritional value of high-lysine maize in humans. In E. T. Mertz (Ed.), Quality protein maize (pp. 205-225). American Association of Cereal Chemistry, St Paul, Minnesota.

Campbell, J. (2002). A critical appraisal of participatory methods in development research. International Journal of Social Research Methodology, 5, 19-29. http://dx.doi.org/10.1080/13645570110098046

Chambers, R. (1994a). The origins and practice of Participatory Rural Appraisal. World Development, 22, 953-969. http://dx.doi.org/10.1016/0305-750X(94)90141-4

Cleaver, F. (2001). Institutions, agencies and the limits of participatory approaches to development. In B. Cooke \& U. Kothari (Eds.), Participation: The new tyranny? (pp. 36-55). Zed, London.

Cornwall, A., Gujit, I., \& Wellbourn, A. (1993). Acknowledging Process: Challenges for Agricultural Research and Extension Methodology. Sussex University, Sussex.

Derera, J., Tongoona, P., Langyintuo, A., Laing, M. D., \& Vivek, B. (2006). Farmer perceptions on maize cultivars in the marginal eastern belt of Zimbabwe and their implications for breeding. African Crop Science Journal, 14, 1-15. 
DeVries, J., \& Toenniessen, G. (2001). Securing the harvest: Biotechnology, breeding and seed systems for African crops. The Rockefeller Foundation, CABI publishing, New York, USA. Retrieved from $\mathrm{http} / / /$ www.un.org/millenniumgoals/pdf/nyas_building_agra.pdf

Doswell, C. R., Paliwal, R. I., \& Cantrell, R. P. (1996). Maize in the third world. Westview Press, Colorado, USA.

Falconer, D. S., \& Mackay, T. F. C. (1996). Introduction to quantitative genetics. Fourth ed. Longman Group.

FAOSTAT. (2012). FAOSTAT data 2012. FAO. Retrieved March 31, 2012, from http://faostat.fao.org/site/567/

Gladwin, C. H., Peterson, J. S., \& Mwale, A. C. (2002). The quality of science in participatory research: A case

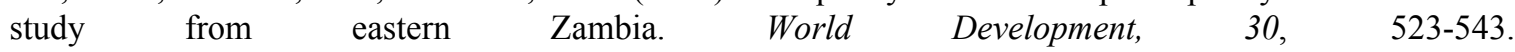
http://dx.doi.org/10.1016/S0305-750X(02)00002-5

Godfrey, S., \& Obika, A. (2004). Improved community participation: Lessons from water supply programmes in Angola. Community Development Journal, 39, 156-165. http://dx.doi.org/10.1093/cdj/39.2.156

Gonsalves, J., Becker, T., Braun, A., Campilan, D., Da Chavez, H., Fajber, E., ... Vernooy, R., (2005). Participatory research and development: A sourcebook overview. In Participatory research and development for sustainable agriculture and natural resource management: A sourcebook. Volume 1: Understanding participatory research and development. International Potato Centre users' perspectives with agricultural research and development, Laguna, Philippines and International Development research Centre, Ottawa, Canada, ed. Gonsalves et al, iii - v.

Graham, G. G., Lembcke, J., \& Morales, E. (1990). Quality-protein maize as the sole source of dietary protein and fat for rapidly growing young children. Paediatrics, 85, 85-91.

Gunaratna, N. S., Groote, H. D., Nestel, P., Pixley, K. V., \& McCabe, G. P. (2010). A meta-analysis of community-based studies on quality protein maize. Food Policy, 35, 202-210. http://dx.doi.org/10.1016/j.foodpol.2009.11.003

Krivanek, A. F., De Groote, H., Gunaratna, N. S., Diallo, A., \& Friesen, D. (2007). Breeding and disseminating quality protein maize (QPM) for Africa. African Journal of Biotechnology, 6, 312-324.

Langyintuo, A. S., Ntoukam, G., Murdock, L., Lowenberg-Deboer, J., \& Miller, D. J. (2004). Consumer preferences for cowpea in Cameroon and Ghana. Agricultural Economics, 30, 203-213. doi: 10.1111/j.1574-0862.2004.tb00189

Machida, L., Derera, J., Tongoona, P., \& MacRobert, J. (2010). Combining ability and reciprocal cross effects of elite quality protein maize inbred lines in subtropical environments. Crop Science, 50, 1708-1717. http://dx.doi.org/10.2135/cropsci2009.09.0538

Machida, L., Derera, J., Tongoona, P., Mutanga, O., \& MacRobert, J. (2012). Geostatistical analysis of quality protein maize outcrossing with pollen from adjacent normal endosperm maize varieties. Crop Science, 52, 1235-1245. http://dx.doi.org/10.2135/cropsci2011.08.0448

MedicineNet.com. (1998). Webster's New World Medical Dictionary [Online]. Retrieved June 28, 2012, from $\mathrm{http}: / / \mathrm{www}$. medterms.com/script/main/art.asp?articlekey $=4124$

Modi, A. (2002). Indigenous storage method enhances seed vigour of traditional maize. South African Journal of Science, 98, 138-139.

Modi, A. (2004). Short term preservation of maize landrace seed and taro propagules using indigenous storage methods. South African Journal of Botany, 70, 15-23. http://dx.doi.org/10.4314\%2Fsajb.v70i1.20652

Narayan, D. (1993). Focus on participation: Evidence from 121 rural water supply projects. World Bank, Washington, D.C.

Pretty, J. N., Guijt, I., Scoones, I., \& Thompson, J. (1995). A trainer's guide for participatory learning and action. International Institute for Environment and Development. London, UK.

Pretty, J. N., \& Voudouhue, S. D. (1996). Chapter 6 - Using rapid or participatory rural appraisal. In B. E. Swanson, et al. (Eds.), Improving agricultural extension: A reference manual. FAO, Rome.

Prokopy, L. S. (2005). The Relationship between participation and project outcomes: Evidence from rural water supply projects in India. World Development, 33, 1801-1819. http://dx.doi.org/10.1016/j.worlddev.2005.07.002

Rubey, L., Ward, R. W., \& Tschirley, D. (1997). Maize research priorities: The role of consumer preferences. In D. Byerlee \& C. K. Eicher (Eds.), Africa's Emerging Maize Revolution (pp. 145-155). Lynne Rienner Publishers, 
Boulder Colorado USA and London UK. Retrieved from https://www.rienner.com/title/Africa_s_Emerging_Maize_Revolution

Rusike, J. (1998). Zimbabwe. In M. L. Morris (Ed.) Maize Seed Industries in Developing Countries (pp. 303-319). Lynne Rienner Publishers in association with CIMMYT. Retrieved from https://www.rienner.com/title/Maize_Seed_Industries_in_Developing_Countries

Saunders, M. N. K., Lewis, P., \& Thornhill, A. (1997). Research methods for business students. London: Pitman Publishing.

Smale, M., \& Heisey, P. (1994). Maize research in Malawi revisited: An emerging success story? Journal of International Development, 6, 689-706. http://dx.doi.org/10.1002/jid.3380060603

Snapp, S., (2002). Quantifying farmer evaluation of technologies: The mother baby trial design. In M. R. Bellon \& J. Reeves (Eds.), Quantitative analysis of data from participatory methods in plant breeding. Mexico, D. F.: CIMMYT. Retrieved from http://repository.cimmyt.org/xmlui/bitstream/handle/10883/909/448231.pdf

Twumasi-Afriye, S., Dzah, B. D., \& Ahenkora, K. (1996). Why QPM moved in Ghana. p. 28-31. In J. K. Ransom, et al. (Eds.), Maize productivity gains through research and technology dissemination: Proceedings of the fifth Eastern and Southern Africa regional maize conference, held in Arusha, Tanzania, 3-7 June 1996. Addis Ababa, Ethiopia: CIMMYT.

UNICEF, WHO, The World Bank. (2012). United Nations Children's Fund, World Health Organization, The World Bank. UNICEF-WHO- World Bank Joint Child Malnutrition Estimates. (UNICEF, New York; WHO, Geneva; The World Bank, Washington, DC; 2012). Levels and trends in child malnutrition: UNICEF-WHO-The World Bank joint child malnutrition estimates. Retrieved from http://www.who.int/nutgrowthdb/jme_unicef_who_wb.pdf

Vasal, S. K. (2001). High quality protein corn. In A. R. Hallauer (Ed.), Specialty corns (pp. 85-129). CRC Press, Boca Raton, FL. Retrieved from http://pustakapertanianub.staff.ub.ac.id/files/2012/12/Specialty-Corns.pdf

Vasal, S. K. (2002). The role of high lysine cereals in animal and human nutrition in Asia. pp. 167. Protein Sources for the Animal and feed Industry: Expert Consultation and Workshop. Bangkok, 29 April - 3 May 2002. FAO, Bangkok. Retrieved from http://www.fao.org/docrep/007/y5019e/y5019e0b.htm\#bm11

\section{Notes}

Note 1. Mother Baby Trial design: A design where the mother trial contains all the entries in a trial and the baby trials are made up of the different entries organized according to the incomplete blocks that make up the mother trial. The mother trial is managed by researchers and each of the baby trials is managed by a different host farmer. The performance of the entries in the mother trial is systematically cross checked against the performance in the baby trial. The smaller baby trial is easily understood and managed by the farmer.

Note 2. Kwashiorkor is protein calorie malnutrition which can lead to infant morbidity and mortality. It disables the immune system such that the child is susceptible to a host of infectious diseases. The term is from Ivory Coast where it means the deposed child (weaned off).

Note 3. Agribank is the state controlled financial institution that mostly finances farming activities in Zimbabwe.

\section{Copyrights}

Copyright for this article is retained by the author(s), with first publication rights granted to the journal.

This is an open-access article distributed under the terms and conditions of the Creative Commons Attribution license (http://creativecommons.org/licenses/by/3.0/). 